A C G

publications

\title{
Chemical Composition, Antioxidant and Anticholinesterase Activities of the Essential oil of Origanum rotundifolium Boiss. from Turkey
}

\section{Hilal Özbek ${ }^{1}$, Zühal Güvenalp ${ }^{1 *}$, Temel Özek² ${ }^{2}$ Handan G. Sevindik ${ }^{1}$, Hafize Yuca $^{1}$, Kadir Ö. Yerdelen ${ }^{3}$ and Lütfiye Ömür Demirezer ${ }^{4}$}

\author{
${ }^{I}$ Department of Pharmacognosy, Faculty of Pharmacy, Atatürk University, 25240 Erzurum, Türkiye \\ ${ }^{2}$ Department of Pharmacognosy, Faculty of Pharmacy, Anadolu University, 26470 Eskişehir, Türkiye \\ ${ }^{3}$ Department of Pharmaceutical Chemistry, Faculty of Pharmacy, Atatürk University, \\ 25240 Erzurum, Türkiye \\ ${ }^{4}$ Department of Pharmacognosy, Faculty of Pharmacy, Hacettepe University, 06100 Ankara, Türkiye
}

(Received May 27, 2016; Revised November 30, 2016; Accepted December 16, 2016)

\begin{abstract}
The essential oil was obtained by hydrodistillation from the aerial parts of Origanum rotundifolium Boiss. Its chemical content and composition were analyzed by using a gas chromatography (GC-FID) and gas chromatography-mass spectrometry (GC-MS). Total phenolic content of the essential oil was determined as $132.39 \mu \mathrm{g}$ gallic acid equivalent by Folin-Ciocalteu's method and the major component was identified as carvacrol $(56.8 \%)$ along with $p$-cymene $(13.1 \%),(Z)$ - $\beta$-ocimene $(5.4 \%)$, $\beta$-caryophyllene $(3.9 \%)$, borneol $(3.4$ $\%$ ) and thymol (3.2\%). After chemical characterization, the essential oil was evaluated for its antioxidant activity by DPPH free radical, superoxide anion radical and hydrogen peroxide scavenging activities as well as ferrous ion-chelating power test, ABTS radical cation decolorization assay and ferric thiocyanate methods. Besides antioxidant activity, acetylcholinesterase and butyrylcholinesterase inhibitory activities of the essential oil were also evaluated by Ellman's method. It demonstrated inhibitory activities on AChE and BuChE, key enzymes in the pathogenesis of Alzheimer's disease (AD), in addition to significant antioxidant activity.
\end{abstract}

Keywords: Origanum rotundifolium; Essential oil; Antioxidant; Acetylcholinesterase; Butyrylcholinesterase. (C) 2017 ACG Publications. All rights reserved.

\section{Plant Source}

The genus Origanum is a member of the Lamiaceae family and is represented in the flora of Turkey by 24 species and 6 hybrid species [1-3], some of which have been used as sedative, diuretic, diaphoretic, antidiarrheal, digestive and carminative in Turkish folk medicine [4]. O. rotundifolium is a narrowly distributed species that is mainly confined in northeast of Turkey to west of Transcaucasus. [5]. The essential oil of $O$. rotundifolium has been reported to show a variety of biological activities such as antibacterial [6], antigenotoxic, antioxidant [7], antiprobiotic [8] and antimicrobial [9]. In this study, first the chemical composition and total phenolic content of the essential oil from aerial parts of $O$. rotundifolium were determined, and then, its antioxidant capacity, acetylcholinesterase and butyrylcholinesterase inhibitory activities were evaluated.

The aerial parts of wild Origanum rotundifolium Boiss. were collected from Erzurum Taşağ 11 Village $(2400 \mathrm{~m})$ in August 2012 and identified by Mehmet Önal from Regional Directorate of

\footnotetext{
* Corresponding author: E-Mail: guvenalp@atauni.edu.tr;
} 
Forestry, Turkey. The voucher specimen (AUEF 1002) has been deposited in the Herbarium of the Faculty of Pharmacy, Atatürk University, Erzurum, Turkey.

\section{Previous Studies}

Previously, various chemical compositions of $O$. rotundifolium essential oils were studied. The main constituents of the oil obtained from the aerial parts of this species collected from Ardanuç (Turkey) were cis-sabinene hydrate $(21.53 \%)$ and linalyl acetate $(7.48 \%)$ [10]. Major components of the oil obtained from the aerial parts of $O$. rotundifolium collected from Aşkale (Turkey) were thymol $(40.86 \%)$, carvacrol (43.62\%), p-cymene $(5.95 \%)$ and borneol $(2.49 \%)$ [7]. Oil of O. rotundifolium collected from İspir (Turkey) contained mainly carvacrol (54.6\%), p-cymene (12.5\%), borneol $(5.9 \%)$ and thymol $(3.5 \%)$ [9]. Major components of the oil obtained from the aerial parts of $O$. rotundifolium were collected from Borçka (Turkey) were borneol $(28.21 \%)$, o-cymene $(9.55 \%)$, terpinen-4-ol (8.64 \%), and spathulenol (8.89\%) [11]. Variation in essential oil compositions can occur as a result of different soil conditions, altitude, climatic conditions, seasonal factors and other environmental features [12].

A few studies have been reported previously on the anticholinesterase activity of some Origanum species [13-16], but not for O. rotundifolium.

Table 1. Chemical composition of the essential oil from O. rotundifolium

\begin{tabular}{|c|c|c|c|c|c|c|c|}
\hline Compound & RRI $^{\mathrm{a}}$ & RRI $^{\mathbf{b}}$ & $\%^{\mathrm{c}}$ & alloaromadendrene & 1661 & $1659[26]$ & 0.1 \\
\hline tricyclene & 1014 & 1018 [17] & $\mathrm{t}^{\mathrm{d}}$ & $\alpha$-humulene & 1687 & $1675[17]$ & 0.2 \\
\hline$\alpha$-pinene & 1032 & $1032[18]$ & 0.7 & $\gamma$-muurolene & 1704 & $1692[17]$ & 0.2 \\
\hline$\alpha$-thujene & 1035 & 1035 [19] & 0.5 & $\alpha$-terpineol & 1706 & 1694 [17] & 0.3 \\
\hline camphene & 1076 & $1077[17]$ & 0.8 & borneol & 1719 & $1717[26]$ & 3.4 \\
\hline$\beta$-pinene & 1118 & $1117[17]$ & 0.1 & $\alpha$-muurolene & 1740 & $1742[26]$ & 0.1 \\
\hline sabinene & 1132 & $1030[17]$ & $\mathrm{t}$ & $\delta$-cadinene & 1773 & $1774[26]$ & 0.3 \\
\hline thuja-2,4(10)-diene & 1136 & $1135[20]$ & $\mathrm{t}$ & $\gamma$-cadinene & 1776 & $1779[26]$ & 0.1 \\
\hline$\delta$-3-carene & 1159 & 1159 [18] & 0.1 & cadina-1,4-diene & & & \\
\hline myrcene & 1174 & $1174[18]$ & 1.1 & (=cubenene) & 1799 & $1810[26]$ & $\mathrm{t}$ \\
\hline$\alpha$-terpinene & 1188 & $1188[18]$ & 1.0 & myrtenol & 1804 & $1807[26]$ & $\mathrm{t}$ \\
\hline dehydro-1,8-cineole & 1195 & $1195[21]$ & $\mathrm{t}$ & cis-calamenene & 1853 & $1847[26]$ & $\mathrm{t}$ \\
\hline limonene & 1203 & $1203[21]$ & 0.2 & geraniol & 1857 & $1859[26]$ & $\mathrm{t}$ \\
\hline$o$-mentha-1(7),5,8-triene & 1224 & $1224[22]$ & 0.2 & p-cymen-8-ol & 1864 & $1865[26]$ & 0.3 \\
\hline$(Z)-\beta$-ocimene & 1246 & $1241[17]$ & 5.4 & 4-isopropyl salicylaldehyde & 1940 & $1940[32]$ & 0.1 \\
\hline$(E)-\beta$-ocimene & 1266 & $1258[17]$ & 0.1 & caryophyllene oxide & 2008 & $2008[21]$ & 0.8 \\
\hline 3-octanone & 1266 & $1266[23]$ & 1.2 & cumin alcohol & 2113 & $2100[21]$ & 0.1 \\
\hline$p$-cymene & 1280 & $1278[17]$ & 13.1 & spathulenol & 2144 & $2150[33]$ & 0.4 \\
\hline terpinolene & 1290 & $1288[17]$ & 0.2 & eugenol & 2186 & $2186[18]$ & 0.2 \\
\hline 3-octanol & 1393 & $1400[24]$ & 0.1 & thymol & 2198 & $2198[18]$ & 3.2 \\
\hline $\begin{array}{l}\text { trans-linalool oxide } \\
\text { (furanoid) }\end{array}$ & 1450 & $1450[25]$ & $\mathrm{t}$ & $\begin{array}{l}\text { isocarvacrol (=4-isopropyl-2- } \\
\text { methyl phenol) }\end{array}$ & 2221 & $2221[34]$ & $\mathrm{t}$ \\
\hline$\alpha, p$-dimethylstyrene & 1452 & $1457[26]$ & $\mathrm{t}$ & carvacrol & 2239 & $2239[34]$ & 56.8 \\
\hline 1-octen-3-ol & 1452 & $1451[27]$ & 0.6 & $\alpha$-cadinol & 2255 & $2255[21]$ & $\mathrm{t}$ \\
\hline trans-sabinene hydrate & 1474 & $1474[28]$ & 0.1 & caryophylla-2(12),6(13)- & & & \\
\hline cis-linalool oxide (Furanoid) & 1478 & $1478[25]$ & $\mathrm{t}$ & dien-5 $\alpha$-ol & 2324 & $2324[35]$ & $\mathrm{t}$ \\
\hline$\alpha$-copaene & 1497 & $1495[17]$ & 0.1 & (=caryophylladienol II) & & & \\
\hline$\beta$-bourbonene & 1535 & $1535[28]$ & 0.1 & 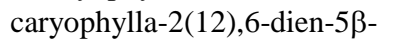 & & & \\
\hline linalool & 1553 & $1553[28]$ & 0.4 & ol (=caryophyllenol II) & 2392 & $2392[35]$ & $\mathrm{t}$ \\
\hline cis-sabinene hydrate & 1556 & $1555[28]$ & $\mathrm{t}$ & & Total & & 98.9 \\
\hline linalyl acetate & 1565 & 1565 [29] & 0.1 & \multirow{5}{*}{\multicolumn{4}{|c|}{$\begin{array}{l}{ }^{\mathrm{a}} \text { Relative retention indices (RRI) calculated against n-alkanes. } \\
{ }^{\mathrm{b}} \text { Relative retention indices (RRI)from literature. } \\
{ }^{\mathrm{c}} \text { The content }(\%) \text { of the individual components was calculated } \\
\text { based on the peak area (FID response). } \\
{ }^{\mathrm{d}} \text { t: Trace }(<0.1 \%) \text {. }\end{array}$}} \\
\hline trans-p-menth-2-en-1-ol & 1571 & $1571[28]$ & $\mathrm{t}$ & & & & \\
\hline$\beta$-ylangene & 1589 & $1589[29]$ & 0.1 & & & & \\
\hline terpinen-4-ol & 1611 & $1611[28]$ & 1.1 & & & & \\
\hline$\beta$-caryophyllene & 1612 & $1612[28]$ & 3.9 & & & & \\
\hline Compound & $\mathbf{R R I}^{\mathbf{a}}$ & $\mathbf{R R I}^{\mathbf{b}}$ & $\%^{\mathrm{c}}$ & & & & \\
\hline $\begin{array}{l}\text { carvacrol methyl ether } \\
(=\text { methyl carvacrol) }\end{array}$ & 1614 & $1604[30]$ & 0.2 & & & & \\
\hline trans-dihydrocarvone & 1624 & $1616[31]$ & 0.1 & & & & \\
\hline aromadendrene & 1628 & $1611[17]$ & 0.5 & & & & \\
\hline cis-isodihydrocarvone & 1645 & $1645[22]$ & 0.2 & & & & \\
\hline
\end{tabular}




\section{Present Study}

Chemical composition of the essential oil: In this study, essential oil was obtained from the aerial parts of $O$. rotundifolium with $1.01 \%$ (w/w) yield. The chemical composition of the essential oil was analyzed by GC-FID and GC-MS analyses. $O$. rotundifolium essential oil was characterized by the presence of sixty two compounds, representing $98.9 \%$ of the total oil. Carvacrol was recognized as the main constituent $(56.8 \%)$ of the total oil composition along with $p$-cymene $(13.1 \%),(Z)-\beta$ ocimene $(5.4 \%), \beta$-caryophyllene $(3.9 \%)$, borneol $(3.4 \%)$ and thymol $(3.2 \%)$. The volatile components identified in the essential oil are presented in Table 1 along with their relative retention indices and percentage composition.

GC analysis of the essential oil was carried out on Agilent 5975 GC-MSD system and Agilent 6890N GC system with flame ionization detector (FID) and a HP-Innowax FSC column (60 m x 0.25 $\mathrm{mm}, 0.25 \mu \mathrm{m}$ film thickness). Helium was used as a carrier gas at $0.8 \mathrm{~mL} / \mathrm{min}$. The injector and detector temperatures were $250^{\circ} \mathrm{C}$ and $300^{\circ} \mathrm{C}$, respectively. GC oven temperature was at $60^{\circ} \mathrm{C}$ for 10 min, and then was programmed to $220^{\circ} \mathrm{C}$ at a rate of $4^{\circ} \mathrm{C} / \mathrm{min}$ and kept in this temperature for $10 \mathrm{~min}$. The oven temperature was finally programmed to $240^{\circ} \mathrm{C}$ at a rate of $1{ }^{\circ} \mathrm{C} / \mathrm{min}$ with a final hold time of $80 \mathrm{~min}$. The split ratio was 40:1. Mass spectra were taken at $70 \mathrm{eV}$, and mass range was from $\mathrm{m} / \mathrm{z} 35$ to 450. In order to obtain same elution order with GC-MS, simultaneous injection was performed by using the same column and appropriate operational conditions.

Total phenolic content of the essential oil: The total phenolic content of the essential oil was determined by using the Folin-Ciocalteu method [36] as gallic acid equivalents using the equation that was obtained from the standard graph (S1). $132.39 \pm 0.12 \mu \mathrm{g}$ gallic acid equivalent of phenolic compounds were detected in $1 \mathrm{mg}$ of essential oil of $O$. rotundifolium. The experiment was repeated at least three times.

Antioxidant activity: Antioxidant activity was evaluated by using six different tests: DPPH free radical scavenging activity [37], ferrous ion-chelating power test [38], ABTS radical cation decolorization assay [39], superoxide anion radical scavenging activity [40], total antioxidant activity by ferric thiocyanate method [41], hydrogen peroxide scavenging activity [42]. All experiments were repeated at least three times. The essential oil of $O$. rotundifolium exhibited significant antioxidant activity measured by scavenging of $\mathrm{ABTS}^{\circ+}, \mathrm{H}_{2} \mathrm{O}_{2}$, and superoxide radical and inhibition of linoleic acid oxidation. As shown in Table 2, the essential oil had scavenging effect on ABTS, $\mathrm{H}_{2} \mathrm{O}_{2}$ and superoxide radical at $60 \mu \mathrm{g} / \mathrm{mL}$ with percentage inhibition of 100,100 and $68.65 \%$, when compared with that of trolox $97.89,81.72$ and $61.36 \%$, respectively. The total antioxidant activity of the essential oil was measured by the inhibition of lipid peroxidation with percentage inhibition of 44.06 $\%$, which was comparable to that of the standard compound (44.71\%). A strong relationship between total phenolic content and antioxidant activity has been reported [11]. Therefore the activity observed for this essential oil should be related to its phenolic content.

Table 2. Antioxidant activity (\%) of the essential oil of $O$. rotundifolium at $60 \mu \mathrm{g} / \mathrm{mL}$

\begin{tabular}{llc}
\hline & Essential Oil $^{\mathbf{a}}$ & Trolox $^{\mathbf{a}}$ \\
\hline ABTS radical cation decolorization activity & $100.00 \pm 0$ & $97.89 \pm 0.21$ \\
DPPH free radical scavenging activity & $6.53 \pm 0.98$ & $45.92 \pm 0.32$ \\
Ferrous ion chelating activity & $21.67 \pm 1.31$ & $59.83 \pm 0.19$ \\
Superoxide anion radical scavenging activity & $68.65 \pm 1.01$ & $61.36 \pm 1.03$ \\
Total antioxidant activity & $44.06 \pm 0.72$ & $44.71 \pm 1.27$ \\
$\mathrm{H}_{2} \mathrm{O}_{2}$ scavenging activity & $100.00 \pm 0$ & $81.72 \pm 0.41$ \\
\hline${ }_{0} \%$ inhibition (mean $\pm S D$ ) & &
\end{tabular}

Anticholinesterase activity: Inhibitory activities of acetylcholinesterase (AChE) and butyrylcholinesterase $(\mathrm{BuChE})$ of the essential oil were evaluated by colorimetric Ellman's method [43], with some modifications using commercially available neostigmine bromide as the reference compound [44]. The experiments were repeated three times for consistency. The essential oil of $O$. rotundifolium showed anticholinesterase activity against acetylcholinesterase with $38.66 \%$ inhibition, and butyrylcholinesterase with $50.66 \%$ inhibition at $25 \mu \mathrm{g} / \mathrm{mL}$ concentration.

On the other hand, the major component carvacrol showed 15.36 and $23.16 \%$ inhibition at the same concentration, respectively (Table 3). The essential oil was more effective than carvacrol. The 
anticholinestrase activity of essential oils is strongly dependent on the interaction of different terpenoid contents, including synergic effect of monoterpenoids [45].

Table 3. In vitro AChE and BuChE inhibition of the essential oil of $O$. rotundifolium at $25 \mu \mathrm{g} / \mathrm{mL}$

\begin{tabular}{llc}
\hline & AChE (\%) & BuChE $\left.^{\mathbf{a}}\right)^{\mathbf{a}}$ \\
\hline Essential oil & $38.66 \pm 1.33$ & $50.66 \pm 2.51$ \\
Carvacrol & $15.36 \pm 0.48$ & $23.16 \pm 0.23$ \\
Neostigmine bromide & $100 \pm 0$ & $100 \pm 0$ \\
\hline
\end{tabular}

a $\%$ inhibition (mean $+S D)$

One of the most important causes of Alzheimer's disease (AD), an oxidative stress-induced neurodegenerative disease, is cholinergic loss in the brain. Specifically, a reduction in the amount of acetylcholine released from cholinergic synapses in Alzheimer's patients has been identified. A treatment method has been developed to increase or protect the amount of acetylcholine by inhibiting acetylcholinesterase [46]. Our study demonstrated that essential oil of $O$. rotundifolium has inhibitory activity on $\mathrm{AChE}$ and $\mathrm{BuChE}$ in addition to significant antioxidant activity. The use of antioxidants may be useful in the treatment of $\mathrm{AD}$ [47]. To the best of our knowledge, this is the first report on cholinesterase inhibitory activity of the essential oil of this plant.

\section{Supporting Information}

Supporting Information accompanies this paper on http://www.acgpubs.org/RNP

\section{References}

[1] K. Tan and A. Carlström (1988). Origanum L. In: Flora of Turkey and East Aegean Islands, Edits., P. H. Davis, R. R. Mill and K. Tan, 10, pp. 206-207, University Press, Edinburgh.

[2] H. Duman (2000). Origanum L., In: Flora of Turkey and East Aegean Islands, University Press, Edits., A. Güner, N. Özhatay, T. Ekim and K.H.C. Başer, 11, pp. 207-208, Edinburgh.

[3] J. H. Ietswaart (1982). Origanum L., In: Flora of Turkey and East Aegean Islands. Edit., P.H. Davis, 7, pp. 297-313, University Press, Edinburgh.

[4] T. Baytop (1999). Türkiye'de Bitkilerle Tedavi (Geçmişte ve Bugün), Nobel Tıp Kitabevleri, İstanbul.

[5] [cited 26/11/2016]. KEW World Checklist of Selected Plant Families [Web Page] 2016; Available from: http://apps.kew.org/wcsp/qsearch.do

[6] F. Dadasoglu, T. Aydin, R. Kotan, A. Cakir, H. Ozer, S. Kordali, R. Cakmakci, N. Dikbas and E. Mete (2011). Antibacterial activities of extracts and essential oils of three Origanum species against plant pathogenic bacteria and their potential use as seed disinfectants, J. Plant Pathol. 93, 271-282.

[7] S. Ceker, G. Nardemir, L. Alpsoy, G. Agar and E. Mete (2012). Anti-genotoxic and anti-oxidant effects of Origanum rotundifolium on human lymphocytes in vitro, J. Essent. Oil Bear. Pl. 15, 415-423.

[8] B. Cetin, S. Cakmakci and M. Gurses (2013). Anti-probiotic effects of essential oils from some Turkish endemic thyme species, Asian J. Chem. 25, 8625-8628.

[9] B. Çetin, S. Çakmakçı and R. Çakmakçı (2011). The investigation of antimicrobial activity of thyme and oregano essential oils, Turk J. Agric. For. 35, 145-154.

[10] K. H. C. Baser, T. Ozek and G. Tumen (1995). Essential oil of Origanum rotundifolium Boiss., J. Essent. Oil Res. 7, 95-96.

[11] I. Goze, A. Alim, A. S. Tepe, M. Sokmen, K. Sevgi and B. Tepe (2009). Screening of the antioxidant activity of essential oil and various extracts of Origanum rotundifolium Boiss. from Turkey, J. Med. Plants Res. 3, 246254.

[12] D. Vokou, S. Kokkini, B. Stella and J. M. Bessiere (1993). Geographic variation of Greek oregano (Origanum vulgare ssp. hirtum) essential oils, Biochem. Syst. Ecol. 21, 287-295.

[13] I. Erdogan Orhan, R. Belhattab, F. S. Senol, A. R. Gülpinar, S. Hosbas and M. Kartal (2010). Profiling of cholinesterase inhibitory and antioxidant activities of Artemisia absinthium, A. herba-alba, A. fragrans, Marrubium vulgare, M. astranicum, Origanum vulgare subsp. glandulossum and essential oil analysis of two Artemisia species, Ind. Crop. Prod. 32, 566-571.

[14] M. R. Loizzo, F. Menichini, F. Conforti, R. Tundis, M. Bonesi, A. M. Saab, G. A. Statti, B. de Cindio, P. J. Houghton, F. Menichini and N. G. Frega (2009). Chemical analysis, antioxidant, antiinflammatory and anticholinesterase activities of Origanum ehrenbergii Boiss and Origanum syriacum L. essential oil, Food Chem. 117, 174-180. 
[15] A. T. H. Mossa and G. A. M. Nawwar (2010). Free radical scavenging and antiacetylcholinesterase activities of Origanum majorana L. essential oil, Hum. Exp. Toxicol. 30, 1501-1513.

[16] I. Orhan, M. Kartal, Y. Kan and B. Sener (2008). Activity of essential oils and individual components against acetyl- and butyrylcholinesterase, Z. Naturforsch. C. 63, 547-553.

[17] T. Feng, J. Cui, Z. Xiao, H. Tian, F. Yi and X. Ma (2011). Chemical Composition of Essential Oil from the Peel of Chinese Torreya grandis Fort, Org. Chem. Int. 1-5 doi:10.1155/2011/187372.

[18] H. Noorizadeh and A. Farmany (2011). Application of GA-PLS and GA-KPLS Calculations for the Prediction of the Retention Indices of Essential Oils, Quim. Nova. 8, 1398-1404.

[19] A. Abdelwahed, N. Hayder, S. Kilani, A. Mahmoud, J. Chibani, M. Hammami, L. Chekir-Ghedira and K. Ghedira (2006). Chemical composition and antimicrobial activity of essential oils from Tunisian Pituranthos tortuosus (Coss.) Maire, Flavour Frag. J. 21, 129-133.

[20] D. E. Wedge, J. A. Klun, N. Tabanca, B. Demirci, T. Ozek, K. H. C. Baser, Z. Liu, S. Zhang, C. L. Cantrel and J. Zhang (2008). Bioactivity-guided fractionation and GC/MS fingerprinting of Angelica sinensis and Angelica archangelica root components for antifungal and mosquito deterrent activity, J. Agric. Food Chem. 57, 464470.

[21] G. Özek, M. Ishmuratova, N. Tabanca, M. M. Radwan, F. Göger, T. Özek, D. E. Wedge, J. J. Becnel, S. J. Cutler and K. H. C. Başer (2012). One-step multiple component isolation from the oil of Crinitaria tatarica (Less.) Sojak by preparative capillary gas chromatography with characterization by spectroscopic and spectrometric techniques and evaluation of biological activity, J. Sep. Sci. 35, 650-660.

[22] M. Kosar, T. Özek, F. Göger, M. Kürkcüoglu and K. H. C. Baser (2005). Comparison of Microwave-Assisted Hydrodistillation and Hydrodistillation Methods for the Analysis of Volatile Secondary Metabolites, Pharm. Biol., 43, 491-495.

[23] K. Héberger and M. Görgényi (1999). Principal component analysis of Kováts indices for carbonyl compounds in capillary gas chromatography, J. Chromatogr., 845, 21-31.

[24] A. Bisio, G. Ciarallo, G. Romussi, N. Fontana, N. Mascolo, R. Capasso and D. Biscardi (1998). Chemical Composition of Essential Oils from some Salvia species, Phytother. Res., 12, 117-120.

[25] D. O. Moronkola, I. A. Ogunwande, I. O. Oyewole, K. H. C. Başer, T. Ozek and G. Ozek (2009). Studies on the volatile oils of Momordica charantia L. (Cucurbitaceae) and Phyllanthus amarus Sch. et Thonn (Euphorbiaceae), J. Essent. Oil Res. 21, 393-399.

[26] C. M. Bignell, P. J. Dunlop and J. J. Brophy (1998). Volatile leaf oils of some south-western and southern Australian species of the genus Eucalyptus (series 1). Part XIX. Flavour Frag. J. 13, 131-139.

[27] M. Hashizume, M. H. Gordon and D. S. Mottram (2007). Light-induced off-flavor development in cloudy apple juice, J. Agric. Food Chem. 55, 9177-9182.

[28] A. Maggio, S. Rosselli, M. Bruno, V. Spadaro, F. M. Raimondo and F. Senatore (2012). Chemical composition of essential oil from Italian populations of Artemisia alba Turra (Asteraceae), Molecules, 17, 10232-10241.

[29] K. H. C. Baser, B. Demirci, M. Kurkcuoglu, F. Satin and G. Tumen (2009). Comparative morphological and phytochemical charactertization of Salvia cadmica and S. smyrnaea, Pak. J. Bot., 41, 1545-1555.

[30] J. Palá-Paúl, J. J. Brophy, R. J. Goldsack and B. Fontaniella (2004). Analysis of the volatile components of Lavandula canariensis (L.) Mill., a Canary Islands endemic species, growing in Australia, Biochem. Syst. Ecol., 32, 55-62.

[31] S. M. Seo, J. Kim, S. G. Lee, C. H. Shin, S. C. Shin and I. K. Park (2009). Fumigant antitermitic activity of plant essential oils and components from Aiowan (Trachyspermum ammi), Allspice (Pimenta dioica), Caraway (Carum carvi), Dill (Anethum graveolens), Geranium (Pelargonium graveolens), and Litsea (Litsea cubeba) oils against Japanese termite (Reticulitermes speratus Kolbe), J. Agric. Food Chem., 57, 6596-6602.

[32] E. M. Suleimenov, G. A. Atazharova, B. Demirci, K. H. C. Baser and S. M. Adekenov (2003). Essential oil composition of Artemisia lercheana and A. sieversiana of Kazakhstan flora in Recent problems of development of new medicines of natural origin in Proceedings of symposium, St.Petersburg - Pushkin.

[33] M. B. Jemia, F. Senatore, M. Bruno and S. Bancheva (2015). Components from the essential oil of Centaurea aeolica Guss. and C. diluta Aiton from Sicily, Italy, Rec. Nat. Prod. 9:4, 580-585

[34] K. H. C. Baser, H. R. Nuriddinov, T. Ozek, A. B. Demirci, N. Azcan and A. M. Nigmatullaev (2002). Essential oil of Arischrada korolkowii from the Chatkal mountains of Uzbekistan, Chem. Nat. Compd. (Engl. Transl.), 38, 51-53.

[35] A. C. U. Lourens, D. Reddy, K. H. C. Baser, A. M. Viljoen and S. F. Van Vuuren (2004). In vitro biological activity and essential oil composition of four indigenous South Africal Helichrysum Species, J. Ethnopharmacol. 95, 253-258.

[36] K. Slinkard and V. L. Singleton (1977). Total phenol analyses: automation and comparison with manual methods, Am. J. Enol. Viticul. 28, 49-55.

[37] M. S. Blois (1958). Antioxidant determinations by the use of a stable free radical, Nature 26, 1199-1200.

[38] T. C. P. Dinis, V. M. C. Madeira and L. M. Almeida (1994). Action of phenolic derivates (acetoaminophen, salycilate, and 5-aminosalycilate) as inhibitors of membrane lipid peroxidation and as peroxyl radical scavengers, Arch. Biochem. Biophys. 315, 161-169.

[39] R. Re, N. Pellegrini, A. Proteggente, A. Pannala, M. Yang and C. Rice-Evans (1999). Antioxidant activity applying an improved ABTS radical cation decolorization assay, Free Radical Bio. Med. 26, 1231-1237. 
[40] J. Zhishen, T. Mengcheng and W. Jianming (1999). The determination of flavonoid contents in mulberry and their scavenging effects on superoxide radicals, Food Chem. 64, 555-559.

[41] H. Mitsuda, K. Yasumoto and K. Iwami (1966). Antioxidative action of indole compounds during the autoxidation of linoleic acid, Eiyoto Shokuryo 19, 210-214.

[42] R. J. Ruch, S. J. Cheng and J. F. Klaunig (1989). Prevention of cytotoxicity and inhibition of intracellular communication by antioxidant catechins isolated from Chinese green tea, Carcinogenesis 10, 1003-1008.

[43] G. L. Ellman, D. Courtney, V. Andies and R. M. Featherstone (1961). A new and rapid colorimetric determination of acetylcholinesterase activity, Biochem. Pharmacol. 7, 88-95.

[44] K. Ö. Yerdelen and E. Tosun (2015). Synthesis, docking and biological evaluation of oxamide and fumaramide analogs as potential AChE and BuChE inhibitors, Med. Chem. Res. 24, 588-602.

[45] I. A. Owokotomo, O. Ekundayo, T. G. Abayomi and A. V. Chukwuka (2015). In-vitro anti-cholinesterase activity of essential oil from four tropical medicinal plants, Toxicol. Rep. 2, 850-857.

[46] D. W. Dickson (1997). Neuropathological diagnosis of Alzheimer's disease: A perspective from longitudinal clinicopathological studies, Neurobiol. Aging, 18, 21-26.

[47] G. E. Gibson and H. M. Huang (2005). Oxidative stress in Alzheimer's disease, Neurobiol. Aging 26, 575-578.

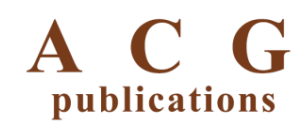

(C) 2017 ACG Publications 